\title{
The effects of ploidy and seed mass on the emergence and early vigour of perennial ryegrass (Lolium perenne L.) cultivars
}

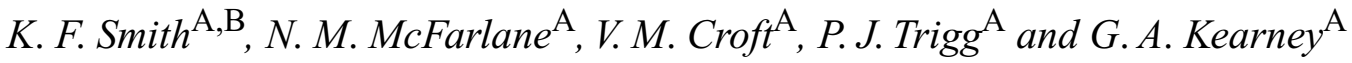 \\ ${ }^{A}$ Department of Primary Industries, Pastoral and Veterinary Institute, \\ Private Bag 105, Hamilton, Vic. 3300, Australia. \\ BAuthor for correspondence; e-mail: kevin.f.smith@nre.vic.gov.au
}

\begin{abstract}
Genetic variation for seed mass and components of early vigour were measured on 120 seedlings of each of 18 diploid and 27 tetraploid perennial ryegrass (Lolium perenne L.) cultivars. Seeds of tetraploid cultivars were on average heavier $(3.8 \mathrm{mg})$ than seed of diploid cultivars $(2.4 \mathrm{mg})$. However, there was variation for mean seed mass both within and between ploidy classes and within cultivars. The components of early vigour measured on each of the seedlings were: date of emergence, leaf appearance rate, seedling height (10 days after germination), leaf length and width and dry matter at 33 days after emergence. Mean seed mass of a cultivar was significantly $(P<0.05)$ positively correlated with seedling height, leaf length, leaf width, shoot length and shoot mass. Individual seed mass within a cultivar was significantly associated with all components of early vigour, except the date of emergence of the second true leaf. There was no difference in the rate of emergence of tetraploid and diploid cultivars, although tetraploid cultivars tended to have longer and wider leaves, greater seedling lengths and fewer leaves and tillers than diploid cultivars. There was also evidence of genetic variation for seedling vigour components in perennial ryegrass after seed mass and ploidy effects had been removed during analysis. These data suggest that seed mass has a large positive effect on early vigour of both diploid and tetraploid cultivars of perennial ryegrass and that, in the absence of any specific knowledge of the early vigour characteristics of a given cultivar, seed mass could be used as a surrogate when choosing between cultivars with similar adaptation and performance.
\end{abstract}

\section{Introduction}

Perennial ryegrass (Lolium perenne L.) is the most important perennial grass species sown in temperate agriculture. In nature, the species exists as a diploid $(2 n=2 x=14)$; however, it is possible to induce tetraploidy $(2 n=4 x=28)$ in perennial ryegrass through the use of colchicine (Morgan 1976). The induction of tetraploidy in perennial ryegrasses leads to changes in the morphology of plants, such as increased seed mass (Sugiyama 1998), increased cell size (Wilkins and Sabanci 1990), increases in the size of leaves and tillers (Neuteboom et al. 1988; Smith et al. 2001) and a decrease in the rate of leaf and tiller appearance (Neuteboom et al. 1988; Smith et al. 2001).

Tetraploid cultivars of perennial ryegrass are not widely sown in Australia, although with several cultivars commercially available their use is likely to increase, as it has done in Europe where tetraploid cultivars are widely sown due to their generally higher forage quality than that of diploids (Castle and Watson 1971; Smith et al. 2001). These increases in forage quality have led to increases in milk (Castle and Watson 1971) and meat production (Vipond et al. 1993, 1997) when combined with appropriate grazing management.

During the establishment of new pastures, perennial ryegrass seedlings often experience competition from annual species such as capeweed (Arctotheca calendula) and Vulpia spp. Competition with weed species has been shown to be a major factor in the establishment of new pasture swards and improvements in early vigour of sown species can lead to more reliable pasture establishment.

In Russian wild ryegrass [Psathyrostachys juncea (Fisch.) Nevski], tetraploid seedlings have been shown to emerge more rapidly and to be larger than diploid seedlings (Berdahl and Rees 1997). The interaction between ploidy and early vigour has received little attention in perennial ryegrass. However, seed mass has been shown to be related to emergence and aspects of early vigour in the diploid perennial ryegrass cultivar S24 (Arnott 1969, 1975). Small seeds of perennial ryegrass cv. S24 had lower leaf and root weights and a reduced ability to emerge when sown at depth, compared with large seeds (Arnott 1975). In general terms, the emergence and early vigour of grass seedlings are related to seed mass, potential mesocotyl and coleoptile elongation, and subsequent growth rates. Although variation in seed mass has been shown to explain a large proportion of the variation in early vigour observed in sand bluestem (Andropogon halii Hack) (Glewen and Vogel 1984) and a number of temperate cereal species (López-Castañeda et al. 1996), in both these instances there was genetic variation for early vigour that was independent of variation in seed weight. It is possible to 
increase the seedling vigour without increasing seed mass through selection for shoot characteristics in the seedling of a number of grass species, such as tall fescue (Festuca arundinacea Schreb.) (Faulkner et al. 1982), sand bluestem (Glewen and Vogel 1985) and bread wheat (Triticum aestivum L.) (Rebetzke and Richards 1999).

This paper presents the results of an experiment where the influence of seed mass and genotype on the emergence and early vigour of a number of diploid and tetraploid perennial ryegrass cultivars was measured.

\section{Materials and methods}

Germplasm

A total of 18 diploid and 27 tetraploid cultivars was used in the experiment. A full list of cultivars, ploidy and country of origin is given in Table 1. All seed had been certified from commercial seed production paddocks and had been cleaned and graded using standard commercial practices. After accession, all samples were stored at low temperature $\left(4^{\circ} \mathrm{C}\right)$ and low humidity before the experiment. Wherever possible, seed was acquired that had been harvested in the season just before the experiment. However, all cultivars were tested for germination before the experiment and only those cultivars with greater than $90 \%$ germination after 14 days were chosen for inclusion in the experiment.

For each cultivar, 120 seeds were randomly selected and weighed into individual Eppendorf tubes to maintain the identity of each seedling.

\section{Sowing}

For each cultivar, 24 plastic pots ( $100 \mathrm{~mm}$ diameter) were numbered and filled with coarse river sand up to within $15 \mathrm{~mm}$ from the rim. Five seeds were equally spaced around the perimeter of each pot, starting from a known point with sowing positions marked on the rim of the pot. The identity of each individual seed was noted to allow comparison to the individual seed weights measured earlier. A further $10 \mathrm{~mm}$ of coarse sand was then added onto each pot. After seedling emergence was recorded, 1 or 2 seedlings were removed from each pot to give 3 seedlings per pot.

\section{Experimental design and randomisation}

Pots were allocated across 6 blocks, with 4 replicates of each block in a latinised row-column design. One pot of each cultivar was placed in each block $\times$ replicate combination. The experiment was located in glasshouse unit at the Pastoral and Veterinary Institute, Hamilton, in the autumn of 1999. Minimum temperatures in the glasshouse did not go below $15^{\circ} \mathrm{C}$ and evaporative cooling was used to keep maximum temperatures to no greater than $30^{\circ} \mathrm{C}$. Pots were watered twice daily, once with water, and once with a complete nutrient solution (Smith 1999).

\section{Plant measurements}

Emergence. After sowing, pots were observed twice daily as before and the number of days taken for each seedling to emerge was recorded.

Leaf appearance. Seedlings were observed daily and the time of emergence of the first and second leaves on each seedling was recorded as the number of days after sowing.

Seedling length. At 10 days after emergence (when the first true leaf had appeared), the lengths of the seedlings were measured. The seedlings were then left undisturbed until the harvest (33-37 days after emergence).

\section{Harvest data}

Seedlings were harvested 33-37 days after emergence and the date of harvest for each seedling was noted. All seedlings in a pot and all pots within a block were harvested on a given day.

At harvesting the number of leaves and tillers of each seedling were counted and recorded. The length and width of the 3 rd leaf of each seedling were also measured. The shoots of each seedling were then dried overnight at $100^{\circ} \mathrm{C}$ and the dry matter of the seedlings recorded.

Statistical analysis

Data from the experiment were analysed using the residual maximum likelihood (REML) procedure in Genstat 5.4 (Genstat 5

Table 1. Origin, ploidy, mean seed weight and range in seed weight (mg) of perennial ryegrass cultivars used in the seedling vigour experiment

\begin{tabular}{|c|c|c|c|c|}
\hline Cultivar & Ploidy & Origin & Mean & Range \\
\hline Aries & $2 x$ & New Zealand & 2.34 & $0.7-4.1$ \\
\hline Banks & $2 x$ & New Zealand & 2.41 & $0.9-3.9$ \\
\hline Dobson & $2 x$ & New Zealand & 2.55 & $1.1-4.4$ \\
\hline Ellett & $2 x$ & New Zealand & 2.65 & $0.7-4.7$ \\
\hline Embassy & $2 x$ & New Zealand & 2.29 & $0.7-3.9$ \\
\hline Fennema & $2 x$ & Germany & 2.36 & $0.8-4.0$ \\
\hline Fitzroy & $2 x$ & Australia & 2.43 & $1.1-4.7$ \\
\hline Grasslands Nui & $2 x$ & New Zealand & 2.51 & $1.2-4.2$ \\
\hline Jumbo & $2 x$ & Denmark & 1.92 & $1.0-3.2$ \\
\hline Kangaroo Valley (early) & $2 x$ & Australia & 2.33 & $0.8-3.6$ \\
\hline Kangaroo Valley (mid) & $2 x$ & Australia & 2.22 & $0.8-3.6$ \\
\hline Kangaroo Valley (late) & $2 x$ & Australia & 1.71 & $0.7-3.3$ \\
\hline Matilda & $2 x$ & Australia & 2.36 & $0.7-5.3$ \\
\hline Moy & $2 x$ & United Kingdom & 2.59 & $0.8-4.9$ \\
\hline Samson & $2 x$ & New Zealand & 2.46 & $1.2-4.3$ \\
\hline Vedette & $2 x$ & New Zealand & 2.58 & $1.2-4.3$ \\
\hline Victorian & $2 x$ & Australia & 2.01 & $1.1-3.5$ \\
\hline $\begin{array}{l}\text { Yatsyn1 } \\
\text { (Diploid mean) }\end{array}$ & $2 x$ & New Zealand & $\begin{array}{c}3.01 \\
(2.38)\end{array}$ & $1.2-5.0$ \\
\hline AberClair & $4 x$ & United Kingdom & 4.15 & $1.6-6.5$ \\
\hline AberGem & $4 x$ & United Kingdom & 5.85 & $2.2-10.0$ \\
\hline AberOnyx & $4 x$ & United Kingdom & 3.60 & $1.1-6.7$ \\
\hline AberOscar & $4 x$ & United Kingdom & 5.06 & $2.2-7.9$ \\
\hline Anaconda & $4 x$ & Netherlands & 3.73 & $1.5-6.6$ \\
\hline BarLP7201 & $4 x$ & Netherlands & 4.44 & $1.7-7.2$ \\
\hline Barfort & $4 x$ & Netherlands & 3.58 & $1.5-6.6$ \\
\hline Barmedia & $4 x$ & Netherlands & 3.78 & $1.6-6.0$ \\
\hline Elgon & $4 x$ & Netherlands & 3.34 & $1.0-5.9$ \\
\hline Fetione & $4 x$ & Netherlands & 3.71 & $1.6-5.9$ \\
\hline Greengold & $4 x$ & Ireland & 3.15 & $1.4-5.8$ \\
\hline Gwendal & $4 x$ & France & 2.58 & $1.2-3.9$ \\
\hline Herbus & $4 x$ & Denmark & 3.08 & $1.0-4.8$ \\
\hline Impala & $4 x$ & Netherlands & 4.19 & $1.7-6.5$ \\
\hline Mandat & $4 x$ & Germany & 3.45 & $1.3-5.6$ \\
\hline Meradonna & $4 x$ & Belgium & 3.40 & $1.3-6.3$ \\
\hline Nevis & $4 x$ & New Zealand & 5.64 & $2.8-8.3$ \\
\hline Pastoral & $4 x$ & France & 3.29 & $1.6-5.4$ \\
\hline Rosalin & $4 x$ & Netherlands & 3.49 & $1.3-5.5$ \\
\hline Sarsfield & $4 x$ & Ireland & 3.81 & $1.8-5.5$ \\
\hline SwTerry & $4 x$ & Sweden & 3.67 & $1.5-5.4$ \\
\hline Tarpan & $4 x$ & Czech Republic & 4.16 & $1.6-6.6$ \\
\hline Tetramax & $4 x$ & Denmark & 3.44 & $1.3-5.5$ \\
\hline Tivoli & $4 x$ & Denmark & 3.24 & $1.4-5.5$ \\
\hline Triton & $4 x$ & Netherlands & 3.56 & $1.3-11.8$ \\
\hline Yatsuboku & $4 x$ & Japan & 3.45 & $1.5-5.8$ \\
\hline $\begin{array}{l}\text { Yatsunami } \\
\text { (Tetraploid mean) }\end{array}$ & $4 x$ & Japan & $\begin{array}{c}2.93 \\
(3.77)\end{array}$ & $1.7-4.5$ \\
\hline 1.s.d. $(P=0.05)$ & & & 0.281 & \\
\hline
\end{tabular}


Committee 1997). The model used for analysis was a mixed model with seed mass and ploidy (with cultivars nested within ploidy levels) analysed as fixed terms for all traits other than the analysis of seed mass. Seedling age at harvest was used as a covariate during analysis. Experimental design parameters such as blocks, replicates, rows, columns and day of harvest were analysed as random terms.

\section{Results}

Seed mass

Seeds of all cultivars were highly viable, with germination greater than $90 \%$ (data not shown). Tetraploid seeds (mean $3.8 \mathrm{mg}$ ) were on average heavier than diploid seeds (mean $2.4 \mathrm{mg})(P<0.01)$. However, there was variation for seed mass both among and within cultivars and ploidy classes (Table 1). For instance, seeds of the diploid cultivar Yatsyn1 had a mean mass $(3.0 \mathrm{mg})$ similar to the mean of all diploid seeds but the mass of individual Yatsyn 1 seeds ranged from 1.2 to $5.0 \mathrm{mg}$. Similar results were obtained with tetraploid cultivars [e.g. the cultivar Tetramax (mean $3.4 \mathrm{mg}$ ) had seeds with masses from 1.3 to $5.3 \mathrm{mg}$ ].

\section{Phenotypic variation in seedling vigour components of perennial ryegrass cultivars}

There was significant variation observed for each of the seedling vigour traits both within and among cultivars.

The phenotypic correlations among the cultivar mean values for each of the seedling vigour traits are presented in Table 2 . Seed mass was significantly $(P<0.01)$ correlated with leaf length, leaf width, seedling length and shoot dry matter. The final shoot weight of the seedlings of a cultivar was also positively correlated with leaf length, leaf width, and seedling length. The rate of emergence of seedlings was not significantly $(P>0.05)$ correlated with the weight of seedlings at the end of the experiment.

\section{Analysis of cultivar, seed mass and ploidy effects on early} vigour components

Significant ploidy and/or cultivar effects were observed for all components of seedling vigour, except for the date of the appearance of the second leaf (data not shown). Seed mass had a positive effect on all of the vigour traits.
Variation in seedling vigour components among perennial ryegrass cultivars within ploidy classes, after adjustment for effects of seed mass

The estimates for components of seedling vigour of ploidy and cultivar after adjustment for seed mass are presented in Table 3. These data show that there is still significant variation among perennial ryegrass for components of early vigour after the major influence of variation for seed mass is taken into account. For instance, the estimates for shoot weight ranged from $56.9 \mathrm{mg}$ (Aberclair) to $82.9 \mathrm{mg}$ (Kangaroo Valley early), as would be expected from the inconsistent differences among cultivars for seed mass and the variation within cultivars (Table 1). The estimates reveal an overlap between tetraploid and diploid cultivars for seedling vigour and seedling vigour components. This result demonstrates the influence of seed mass on the apparent variation for seedling vigour observed among the cultivars. For instance, the diploid cultivars Victorian and Yatsyn1 had adjusted means for seedling mass that were not significantly different from each other $(63.3 v$. $62.9 \mathrm{mg}$ ), whereas the raw means were different by some $20 \mathrm{mg}$ (43.4 v. $61.9 \mathrm{mg}$ ). This result is explained by the fact that Yatsyn1 had the largest seeds of any of the diploid cultivars, yet its seedling mass was only average for diploid cultivars before adjusting for the effects of seed mass. In contrast to this result, the cultivar Kangaroo Valley (early) had relatively small seeds and seedlings with high masses; therefore, its adjusted mean was also high.

\section{Discussion}

Effects of seed mass on seedling vigour of diverse perennial ryegrass cultivars

The mass of an individual seed was a major determinant of all of the components of early vigour of perennial ryegrass that were measured in this experiment, with the exception of the number of days taken for the second true leaf to appear.

Data on the causes of variation in the mass of perennial ryegrass seeds are limited as most researchers have focussed on measuring yield per unit area. However, both genetic and

Table 2. Phenotypic correlations between cultivar mean values for seedling vigour traits in perennial ryegrass

\begin{tabular}{|c|c|c|c|c|c|c|c|c|c|c|}
\hline & $\begin{array}{c}\text { Seed } \\
\text { weight }\end{array}$ & Emergence & $\begin{array}{l}\text { Leaf } \\
\text { length }\end{array}$ & $\begin{array}{l}\text { Leaf } \\
\text { width }\end{array}$ & $\begin{array}{c}\text { Leaf } \\
\text { number }\end{array}$ & $\begin{array}{c}\text { Tiller } \\
\text { number }\end{array}$ & $\begin{array}{l}\text { Shoot } \\
\text { length }\end{array}$ & $\begin{array}{l}\text { Shoot } \\
\text { weight }\end{array}$ & $\begin{array}{c}\text { Leaf-1 } \\
\text { appearance }\end{array}$ & $\begin{array}{c}\text { Leaf-2 } \\
\text { appearance }\end{array}$ \\
\hline Seed weight & - & 0.02 & $0.52 * *$ & $0.68 * * *$ & -0.05 & -0.26 & $0.80^{* * *}$ & $0.65^{* * *}$ & -0.16 & -0.02 \\
\hline Emergence & & - & -0.05 & -0.09 & -0.02 & -0.04 & -0.05 & 0.05 & $0.30 *$ & $-0.31^{*}$ \\
\hline Leaf length & & & - & $0.81 * * *$ & 0.04 & $-0.46 * *$ & $0.47 * *$ & $0.54 * *$ & -0.13 & 0.24 \\
\hline Leaf width & & & & - & 0.02 & $-0.52 * *$ & $0.53 * *$ & $0.53 * *$ & -0.06 & 0.18 \\
\hline Leaf number & & & & & - & $0.48 * *$ & 0.05 & 0.00 & $-0.32 *$ & -0.04 \\
\hline Tiller number & & & & & & - & -0.03 & 0.03 & $-0.30 *$ & -0.07 \\
\hline Shoot length & & & & & & & - & $0.61 * * *$ & -0.27 & 0.06 \\
\hline Shoot weight & & & & & & & & - & -0.24 & 0.07 \\
\hline Leaf-1 appearance & & & & & & & & & - & 0.02 \\
\hline Leaf-2 appearance & & & & & & & & & & - \\
\hline
\end{tabular}

$* P<0.05 ; * * P<0.01 ; * * * P<0.001$. 
environmental factors have been shown to influence the seed mass of perennial ryegrass cultivars in the Netherlands (Elgersma 1990a, 1990b). In that research the seed mass of cultivars was poorly correlated with seed yield per hectare as seed yield was more related to seed number than seed mass
(Elgersma 1990a, 1990b). The seed mass of the cultivars tended to be higher when the seed had been produced in more favourable environmental conditions, although the ranking of the cultivars for seed mass was similar across all environments.

Table 3. Means for early vigour components of perennial ryegrass cultivars adjusted for seed size and ploidy (from REML analyses with seed size and ploidy fitted as fixed effects)

\begin{tabular}{|c|c|c|c|c|c|c|c|c|}
\hline Cultivar & $\begin{array}{l}\text { Shoot DM } \\
(\mathrm{mg})\end{array}$ & $\begin{array}{c}\text { Emergence } \\
\text { (days) }\end{array}$ & $\begin{array}{l}\text { Height } 10 \text { days } \\
\text { post-emergence } \\
(\mathrm{cm})\end{array}$ & $\begin{array}{l}\text { Leaf } 1 \\
\text { (days) }\end{array}$ & $\begin{array}{l}\text { No. of } \\
\text { leaves }\end{array}$ & $\begin{array}{l}\text { 3rd-leaf } \\
\text { length } \\
(\mathrm{cm})\end{array}$ & $\begin{array}{c}\text { 3rd-leaf } \\
\text { width } \\
\text { (mm) }\end{array}$ & $\begin{array}{l}\text { No. of } \\
\text { tillers }\end{array}$ \\
\hline Aries & 71.3 & 5.7 & 9.1 & 11.4 & 4.0 & 23.6 & 3.4 & 3.0 \\
\hline Banks & 65.8 & 5.6 & 9.1 & 11.3 & 4.0 & 24.5 & 3.4 & 2.8 \\
\hline Dobson & 64.3 & 6.1 & 9.5 & 11.3 & 4.0 & 26.5 & 3.6 & 2.6 \\
\hline Ellett & 64.3 & 5.7 & 8.7 & 11.1 & 3.9 & 25.1 & 3.5 & 2.6 \\
\hline Embassy & 69.2 & 6.1 & 9.3 & 11.1 & 3.9 & 25.0 & 3.4 & 3.2 \\
\hline Fennema & 70.7 & 5.4 & 8.5 & 10.8 & 4.0 & 23.5 & 3.3 & 2.7 \\
\hline Fitzroy & 68.5 & 6.3 & 8.5 & 11.3 & 4.0 & 25.0 & 3.4 & 2.9 \\
\hline Grasslands Nui & 62.1 & 6.4 & 9.0 & 11.6 & 3.9 & 25.3 & 3.4 & 2.3 \\
\hline Jumbo & 81.1 & 6.8 & 8.9 & 11.5 & 4.1 & 26.3 & 3.5 & 2.8 \\
\hline Kangaroo Valley (early) & 82.9 & 6.4 & 8.8 & 11.3 & 4.0 & 24.6 & 3.4 & 2.7 \\
\hline Kangaroo Valley (mid) & 68.0 & 6.3 & 8.6 & 11.5 & 4.0 & 23.2 & 3.4 & 2.9 \\
\hline Kangaroo Valley (late) & 68.9 & 6.6 & 8.7 & 11.3 & 4.0 & 23.6 & 3.2 & 2.8 \\
\hline Matilda & 68.2 & 6.7 & 8.8 & 11.4 & 3.9 & 25.0 & 3.5 & 2.7 \\
\hline Moy & 67.6 & 5.9 & 8.4 & 11.2 & 4.0 & 24.0 & 3.4 & 3.0 \\
\hline Samson & 66.2 & 7.1 & 8.4 & 11.5 & 4.0 & 24.9 & 3.4 & 2.7 \\
\hline Vedette & 64.9 & 5.8 & 9.1 & 11.2 & 4.0 & 24.9 & 3.3 & 2.8 \\
\hline Victorian & 63.3 & 6.5 & 9.0 & 11.7 & 3.9 & 23.3 & 3.3 & 2.9 \\
\hline Yatsyn1 & 62.9 & 6.1 & 9.0 & 11.3 & 3.9 & 23.5 & 3.2 & 2.8 \\
\hline AberClair & 56.9 & 6.2 & 8.4 & 11.2 & 3.9 & 23.0 & 3.4 & 2.5 \\
\hline AberGem & 58.6 & 6.4 & 8.8 & 11.7 & 3.9 & 23.5 & 3.4 & 2.4 \\
\hline AberOnyx & 63.2 & 6.7 & 9.0 & 11.6 & 4.0 & 24.2 & 3.5 & 2.4 \\
\hline AberOscar & 76.6 & 5.9 & 9.0 & 11.2 & 4.0 & 25.2 & 3.6 & 2.9 \\
\hline Anaconda & 70.8 & 5.7 & 9.2 & 11.1 & 4.0 & 25.4 & 3.2 & 3.1 \\
\hline BarLP7201 & 66.8 & 6.9 & 8.9 & 11.5 & 4.0 & 21.7 & 3.2 & 3.2 \\
\hline Barfort & 76.5 & 6.2 & 8.5 & 11.3 & 3.9 & 24.0 & 3.4 & 2.8 \\
\hline Barmedia & 65.2 & 5.9 & 9.3 & 11.3 & 4.0 & 23.5 & 3.3 & 2.9 \\
\hline Elgon & 67.5 & 5.2 & 8.6 & 10.9 & 4.0 & 25.0 & 3.4 & 2.7 \\
\hline Fetione & 67.6 & 5.6 & 8.8 & 11.1 & 4.0 & 25.5 & 3.4 & 2.7 \\
\hline Greengold & 71.7 & 6.0 & 9.5 & 11.2 & 3.9 & 24.4 & 3.4 & 2.8 \\
\hline Gwendal & 69.9 & 6.5 & 8.7 & 11.4 & 4.0 & 25.5 & 3.7 & 3.0 \\
\hline Herbus & 72.3 & 7.2 & 8.7 & 11.6 & 4.0 & 24.8 & 3.4 & 2.9 \\
\hline Impala & 74.7 & 5.7 & 9.4 & 11.2 & 4.0 & 26.5 & 3.7 & 3.0 \\
\hline Mandat & 65.3 & 8.2 & 8.3 & 11.6 & 4.0 & 26.0 & 3.6 & 2.6 \\
\hline Meradonna & 65.6 & 5.5 & 8.8 & 11.3 & 4.0 & 24.0 & 3.2 & 2.9 \\
\hline Nevis & 56.5 & 5.8 & 8.8 & 11.2 & 3.9 & 24.1 & 3.5 & 2.4 \\
\hline Pastoral & 67.0 & 5.8 & 8.8 & 11.2 & 4.0 & 23.0 & 3.4 & 2.8 \\
\hline Rosalin & 77.3 & 6.4 & 8.8 & 11.6 & 3.9 & 22.2 & 3.2 & 3.0 \\
\hline Sarsfield & 70.9 & 7.1 & 9.1 & 11.6 & 4.0 & 25.2 & 3.5 & 2.6 \\
\hline SwTerry & 70.1 & 6.6 & 9.0 & 11.1 & 4.1 & 24.8 & 3.3 & 3.0 \\
\hline Tarpan & 66.2 & 5.6 & 8.8 & 11.2 & 3.9 & 24.3 & 3.4 & 2.8 \\
\hline Tetramax & 68.0 & 5.7 & 8.9 & 11.2 & 3.9 & 26.2 & 3.5 & 2.8 \\
\hline Tivoli & 67.4 & 5.4 & 8.9 & 11.0 & 4.0 & 26.1 & 3.9 & 2.7 \\
\hline Triton & 69.2 & 5.5 & 9.4 & 11.3 & 4.0 & 25.9 & 3.6 & 3.0 \\
\hline Yatsuboku & 66.1 & 7.7 & 8.8 & 11.7 & 4.0 & 25.9 & 3.9 & 2.5 \\
\hline Yatsunami & 79.6 & 5.6 & 9.4 & 11.0 & 4.1 & 26.9 & 3.7 & 3.1 \\
\hline 1.s.d. $(P=0.05)$ & 3.60 & 0.32 & 0.25 & 0.16 & 0.08 & 0.92 & 0.19 & 0.18 \\
\hline
\end{tabular}


There is evidence that variation in seed mass within a perennial ryegrass cultivar is associated with the position of a developing seed within a spikelet (Anslow 1964) and interactions between seeds within a spikelet (Warringa et al. $1998 a$ ). This variation within spikelets has been shown to be more important than variation among spikelets on a head (Warringa et al. 1998b).

\section{Effects of ploidy on seedling vigour}

In this experiment tetraploid seedlings tended to be heavier and have larger leaves than diploids. This effect of ploidy was shown largely to be associated with the increased seed mass of tetraploid cultivars compared with diploid cultivars, although there was considerable variation and overlap between the mean seed mass of diploid and tetraploid cultivars. Similar effects have been observed in Russian wild ryegrass, where seeds of induced tetraploid cultivars were heavier and resulted in heavier seedlings with larger leaves than diploid cultivars (Berdahl and Rees 1997).

Ploidy was shown to have effects on shoot characters such as leaf length, leaf width, mesocotyl length and number of tillers. The results obtained in this experiment were consistent with those obtained with mature perennial ryegrass plants (Neuteboom et al. 1988; Smith et al. 2001) or with seedlings of other species (Berdahl and Rees 1997), with tetraploid plants tending to have fewer tillers and larger leaves than diploid plants.

The broad range of tetraploid and diploid cultivars sown in this experiment has demonstrated that there is variability both within and between ploidy classes for both seed mass and seedling vigour traits. The causes of this variation are poorly understood. However, induced polyploidy is known to increase the cell size and volume of plant species. This is known as the 'Gigas' effect and it is possible that genetic effects on auxin concentrations, cell wall extensibility and cell size between and within diploid and tetraploid perennial ryegrass cultivars may explain part of this variation. Wilkins and Sabanci (1990) measured the size and shape of leaf epidermal cells of 6 diploid perennial ryegrass populations and the tetraploid cv. Tove. The diploids varied in cell length by $26 \%$ and cell width by $9 \%$ and on average the cells of cv. Tove were $25 \%$ longer and $12 \%$ wider than the highest-ranking diploid, although there was an overlap between the largest cells in the highest-ranking diploid populations and $\mathrm{cv}$. Tove.

As both cell expansion and cell multiplication have been shown to be important in leaf expansion in Lolium (Volenec and Nelson 1981) and the differences in cell dimensions observed in diploid perennial ryegrass appear to be under the control of specific genes rather than variations in DNA content (Wilkins and Sabanci 1990), it is possible that the variation in seedling growth observed in this experiment was due to differences in a range of genetic factors among cultivars within ploidy classes.
Variation in early vigour independent of seed mass effects

Although seed mass was an important determinant of seedling vigour components, there was considerable variation in the adjusted means of cultivars for all seedling vigour traits after the effect of seed mass was taken into account. There is relatively little information on the genetic variation that exists in grass species for seedling vigour components after the effects of seed mass have been removed. Variation in embryo size has been shown to be an important determinant of early vigour among a number of cereal species (López-Castañeda et al. 1996) and seedling leaf breadth has been shown to be an effective selection criterion to increase the early vigour of bread wheat (Rebetzke and Richards 1999). Genetic variation in seedling vigour independent of seed mass has been observed in seedling yield of sand bluestem (Glewen and Vogel 1984) and in early tiller development in tall fescue (Lewis and Garcia 1979).

\section{Practical implications}

Large variations in seed mass were measured among commercial seed lines of a number of diploid and tetraploid perennial ryegrass cultivars and this variation in seed mass was strongly associated with differences in seedling vigour components. Reduction in the thousand-seed mass of perennial ryegrass seed crops grown under stress conditions such as late sowing has also recently been shown to reduce the seedling vigour of the seeds when sown under a range of conditions (Cookson et al. 2001). These data demonstrate that a higher mean seed mass of perennial ryegrass could be used to discriminate among seed lots within a cultivar when purchasing seeds or among cultivars with similar agronomic adaptation but contrasting thousand-seed mass.

During pasture establishment about $90 \%$ of those grass seedlings that germinate die within 3 months of sowing (Charles 1961), reflecting the intense within- and among-species competition that grass seedlings face in a newly established sward. Recent data from Australia (Waller et al. 1999) and New Zealand (Sanders et al. 1989) suggest that seedling recruitment by perennial ryegrass may be a more important mechanism of maintaining perennial ryegrass density than previously thought, especially under some grazing regimes. There is also an increasing move towards oversowing to introduce new cultivars to renovate swards. In both of these instances, newly germinated perennial ryegrass seedlings will have to compete with both annual and perennial sown species and weeds.

Shoot characteristics such as coleoptile tiller development (Lewis and Garcia 1979) and coleoptile and mesocotyl length and thickness (Andrews et al. 1997) have been shown to be important characteristics related to the early vigour of forage grass species, especially in stress environments. Our data demonstrate that when seed mass effects are removed there is still considerable variation for a range of seedling 
vigour components in perennial ryegrass cultivars. While the mechanisms causing this variation are not well understood, results with other grass species (Glewen and Vogel 1984; Rebetzke and Richards 1999) have shown that the variation for seedling vigour traits free of seed mass effects is moderately to highly heritable and that it is possible to increase seedling vigour without selecting for larger seeds. By selecting for seedling vigour while maintaining seed mass, seed yields with respect to numbers are also maintained.

\section{References}

Andrews M, Douglas A, Jones AV, Milburn CE, Porter D, McKenzie BA (1997) Emergence of temperate pasture grasses from different sowing depths: importance of seed weight, coleoptile plus mesocotyl length and shoot strength. Annals of Applied Biology 130, 549-560.

Anslow RC (1964) Seed formation in perennial ryegrass. II. Maturation of seed. Journal of the British Grassland Society 19, 349-357.

Arnott RA (1969) The effect of seed weight and depth of sowing on the emergence and early seedling growth of perennial ryegrass (Lolium perenne). Journal of the British Grassland Society 24, 104-110.

Arnott RA (1975) A quantitative analysis of the endosperm-dependent seedling growth in grasses. Annals of Botany 39, 757-765.

Berdahl JD, Rees RE (1997) Development and vigor of diploid and tetraploid Russian wildrye seedlings. Journal of Range Management 50, 80-84.

Castle ME, Watson JN (1971) A comparison between a diploid and a tetraploid ryegrass for milk production. Journal of Agricultural Science, Cambridge 77, 69-76.

Charles AH (1961) Differential survival of cultivars of Lolium, Dactylis and Phleum. Journal of the British Grassland Society 16, 69-75.

Cookson WR, Rowarth JS, Sedcole JR (2001) Seed vigour in perennial ryegrass (Lolium perenne L.): effect and cause. Seed Science and Technology 29, 255-270.

Elgersma A (1990a) Genetic variation for seed yield in perennial ryegrass (Lolium perenne L.). Plant Breeding 105, 117-125.

Elgersma A (1990b) Seed yield related to crop development and to yield components in nine cultivars of perennial ryegrass (Lolium perenne L.) Euphytica 49, 141-154.

Faulkner JS, Johnston F, McAneney DMP (1982) Selection and seedling vigour in Festuca arundinacea. Journal of Agricultural Science, Cambridge 99, 173-184.

Genstat 5 Committee (1997) 'Genstat 5 release 4.1 reference manual.' (Clarendon Press: Oxford)

Glewen KL, Vogel KP (1984) Partitioning the genetic variability for seedling growth in sand bluestem into its seed size and seedling vigor components. Crop Science 24, 137-141.

Lewis EJ, Garcia JA (1979) The effect of seed weight and coleoptile tiller development on seedling vigour in tall fescue, Festuca arundinacea Screb. Euphytica 28, 393-402.

López-Castañeda C, Richards RA, Farquhar GD, Williamson RE (1996) Seed and seedling characteristics contributing to variation in early vigor among temperate cereals. Crop Science 36, 1257-1266.
Morgan WG (1976) A technique for the production of polyploids in grasses. Euphytica 25, 433-466.

Neuteboom JH, Lantinga EA, Wind K (1988) Tillering characteristics of diploid and tetraploid perennial ryegrass. In 'Proceedings of the 12th general meeting of the European Grassland Federation'. pp. 498-503. (Irish Grassland Association: Tuam, Ireland)

Rebetzke GJ, Richards RA (1999) Genetic improvement of early vigour in wheat. Australian Journal of Agricultural Research 50, 291-301.

Sanders PM, Barker DJ, Wewala GS (1989) Phosphoglucoisomerase-2 allozymes for distinguishing perennial ryegrass cultivars in binary mixtures. Journal of Agricultural Science, Cambridge 112, 179-184.

Smith KF (1999) The genetics and physiology of water soluble carbohydrates in perennial ryegrass (Lolium perenne $\mathrm{L}$.). $\mathrm{PhD}$ Thesis, The University of Melbourne.

Smith KF, Simpson RJ, Culvenor RA, Humphreys MO, Prud'homme MP, Oram RN (2001) The effects of ploidy and a phenotype conferring a high-water soluble carbohydrate concentration on carbohydrate accumulation, nutritive value and morphology of perennial ryegrass (Lolium perenne L.). Journal of Agricultural Science, Cambridge 136, 65-74.

Sugiyama S (1998) Differentiation in competitive ability and cold tolerance between diploid and tetraploid cultivars in Lolium perenne. Euphytica $\mathbf{1 0 3}, 55-59$.

Vipond JE, Swift G, McClelland TH, Fitzsimons J, Hunter EA (1997) A comparison of diploid and tetraploid perennial ryegrass and tetraploid ryegrass/white clover swards under continuous sheep stocking at controlled sward heights. 3. Sward characteristics and animal output, years 4-8. Grass and Forage Science 52, 99-109.

Vipond JE, Swift G, McClelland TH, Fitzsimons J, Milne JA, Hunter EA (1993) A comparison of diploid and tetraploid perennial ryegrass and tetraploid ryegrass/white clover swards under continuous sheep stocking at controlled sward heights. 2. Animal production. Grass and Forage Science 48, 290-300.

Volenec JJ, Nelson CJ (1981) Cell dynamics in leaf meristems of contrasting tall fescue genotypes. Crop Science 21, 381-385.

Waller RA, Sale PWG, Saul GR, Quigley PE, Kearney GA (1999) Tactical versus continuous stocking for persistence of perennial ryegrass (Lolium perenne L.) in pastures grazed by sheep in south-western Victoria. Australian Journal of Experimental Agriculture 39, 265-274.

Warringa JW, Struik PC, Kreuzer ADH (1998b) The pattern of flowering, seed set, seed growth and ripening along the ear of Lolium perenne L. Australian Journal of Plant Physiology 25, 213-223.

Warringa JW, Visser R de, Kreuzer ADH (1998a) Seed weight in Lolium perenne as affected by interactions among seeds within the inflorescence. Annals of Botany 82, 835-841.

Wilkins PW, Sabanci CO (1990) Genetic variation in leaf epidermal cell size and shape in Lolium perenne. Euphytica 47, 233-239.

Received 31 August 2001, accepted 18 November 2002 